\title{
A comparative study between intramuscular oxytocin and intramuscular methyl ergometrine in the active management of third stage of labour
}

\author{
Devi Reddy Hema Swapnika*, Prema Priya G., S. Senthil Priya, A. S. Allirathinam
}

Department of Obstetrics and Gynecology, Vinayaka Mission Kirupananda Variyar Medical College and Hospital, Salem, Tamil Nadu, India

Received: 28 February 2018

Accepted: 28 March 2018

\section{*Correspondence:}

Dr. Devi Reddy Hema Swapnika,

E-mail: hswapnika@gmail.com

Copyright: () the author(s), publisher and licensee Medip Academy. This is an open-access article distributed under the terms of the Creative Commons Attribution Non-Commercial License, which permits unrestricted non-commercial use, distribution, and reproduction in any medium, provided the original work is properly cited.

\section{ABSTRACT}

Background: To compare the efficacy of prophylactic IM oxytocin 10U and IM methyl ergometrine $0.2 \mathrm{mg}$ on duration of third stage of labour, amount of blood loss during the third stage of labour and associated side effects.

Methods: 50 low risk antenatal women with singleton pregnancy at term gestation in vertex presentation admitted for vaginal delivery, were randomly allocated into 2 groups of 25 each and managed actively in the third stage of labour either with $10 \mathrm{U}$ oxytocin IM or with $0.2 \mathrm{mg}$ methyl ergometrine IM immediately after the birth of the baby. The main outcome measures were the difference between the 2groups with regard to: duration of third stage of labour, blood loss by volume, difference in haemoglobin and haematocrit, need for blood transfusion, additional uterotonics and side effects of drugs.

Results: The mean duration of third stage of labour in the oxytocin group was $6.68 \pm 2.17 \mathrm{~min}$ and in methergine group was $6.4 \pm 1.93 \mathrm{~min}$. Mean blood loss was $302 \pm 75.6 \mathrm{ml}$ and $282.8 \pm 58.27 \mathrm{ml}$. Mean fall in $\mathrm{Hb}$ was $0.92 \mathrm{gm} \%$ and $0.812 \mathrm{gm} \%$. Mean fall in PCV was $2.36 \%$ and $1.88 \%$. 2women in oxytocin group and 1woman in methergine group received additional $0.2 \mathrm{mg}$ methergine. 3 women in both groups received 1unit of blood transfusion. 8women who received methergine had side effects while only one in the oxytocin group, with a p value 0.004 which is statistically significant.

Conclusions: This study has shown that both oxytocin and methylergometrine were equally efficacious. However, oxytocin had significantly better safety profile and lesser contraindications for usage.

Keywords: Active management of third stage of labour, Methyl ergometrine, Oxytocin, Post partum haemorrhage

\section{INTRODUCTION}

Pregnancy and child birth involve health risks for women even without any pre-existing health problems. Maternal mortality ratio (MMR) is used as a measure of the quality of health care system.

The third stage of labour is that period from delivery of the fetus to completed delivery of the placenta and its attached membranes. Relatively little thought or teaching is devoted to the third stage of labour compared with that given to the first and second stages. "This indeed is the unforgiving stage of labour, and in it there lurks more unheralded treachery than in both the other stages combined. The normal case, within a minute, can become abnormal and successful delivery can turn swiftly to disaster" (Donald, 1979). This statement aptly describes the need for proper management of third stage of labour. 
MMR in India is 174/100,000 live births (2011-2015) and $28 \%$ of maternal deaths are due to $\mathrm{PPH} .{ }^{1} \mathrm{PPH}$ usually ranks in the top four causes of maternal mortality in developing countries along with hypertension, infection and unsafe abortions. ${ }^{2}$ Anaemia is one of the most common cause of maternal morbidity and mortality in our country.

The best management of the third stage would be one that effectively minimizes serious problems such as blood loss and retained placenta, while interfering as little as possible with the physiological mechanisms of placental delivery and bonding between mother and baby and has few side effects. Recent studies show that there are still wide variations in practice around the world in the management of third stage of labour.

The present study was done to study the efficacy of 10 units of oxytocin given intramuscularly versus the use of methyl ergometrine $0.2 \mathrm{mg}$ intramuscularly in the active management of third stage of labour for the prevention of post partum haemorrhage.

\section{METHODS}

This was a prospective comparative study conducted in the department of Obstetrics and Gynaecology at VMKV Medical College and Hospital, Salem, during the period from January 2016 to June 2017. 50 low risk women with singleton pregnancy at term gestation with spontaneous onset of labour, admitted for vaginal delivery were eligible for the study.

\section{Exclusion criteria}

Grand multi, malpresentation, multiple pregnancy, gestational age $<37$ weeks and $>41$ weeks, Hydramnios, intra uterine fetal demise, ante partum haemorrhage, previous history of post partum haemorrhage, instrumental delivery, caesarean section, fibroid complicating pregnancy, scarred uterus, medical disorders like severe anaemia $(\mathrm{Hb}<7 \mathrm{~g} / \mathrm{dl})$, hypertension, cardiac disease, asthma, allergic disorders, blood dyscrasias.

Informed consent was obtained from women in early stage of labour who were eligible for the study. 50 women were randomised to 2 groups, 25 in each group, either to receive $10 \mathrm{U}$ oxytocin IM or $0.2 \mathrm{mg}$ methyl ergometrine IM immediately after the birth of the baby. The third stage of labour was managed by clamping and cutting the cord immediately after the delivery of the baby, controlled cord traction and uterine massage. A flat bowl was kept under the buttocks of the women after the delivery of the placenta. Episiotomy wound repaired. Maternal pulse, BP was recorded immediately after delivery. One hour later the blood collected in the bowl was transferred to a measuring jar calibrated in $\mathrm{ml}$ and the amount of blood loss was noted.

\section{Parameters studied}

- Duration of third stage of labour

- Postpartum blood loss

- $\mathrm{Hb} \%$ and PCV measured both before delivery at the time of admission and 24hours after delivery.

- Need for additional uterotonics

- Need for blood transfusion

- Side effects of uterotonics used

- Haemodynamically stable women were discharged from hospital after 24hours of delivery.

\section{Statistical analysis}

Data was entered in excel sheet and analysed using students paired t-test, student unpaired t-test and SPSS version 21 . $P$ value of $<0.05$ was regarded as statistically significant.

\section{RESULTS}

The total number of cases studied was 50. Age ranged from 19 -36 years. Out of the 50 subjects $34(68 \%)$ were in the age group of 20-25 years, $10(20 \%)$ were in age group 26-30years, $3(6 \%)$ in $<20$ and $>30$ years (Table 1 ).

Table 1: Age distribution of women in oxytocin and methergine group.

\begin{tabular}{|llll|}
\hline Age & Frequency & Oxytocin & Methergine \\
\hline$<20$ & 3 & 2 & 1 \\
\hline $21-25$ & 34 & 16 & 18 \\
\hline $26-30$ & 10 & 5 & 5 \\
\hline$>30$ & 3 & 2 & 1 \\
\hline Total & 50 & 25 & 25 \\
\hline
\end{tabular}

The mean duration of third stage of labour in the oxytocin group was $6.68 \pm 2.17 \mathrm{~min}$ and in methergine group was $6.4 \pm 1.93$ min. $\mathrm{p}$ value $=0.88$ which is statistically insignificant (Table 2).

Table 2: Comparison of duration of third stage of labour in minutes.

\begin{tabular}{|c|c|c|c|}
\hline $\begin{array}{l}\text { Duration of } 3^{\text {rd }} \text { stage of } \\
\text { labour in minutes }\end{array}$ & Mean & Sd & $\mathbf{P}$ \\
\hline Oxytocin & 6.68 & 2.174 & \multirow{2}{*}{0.88} \\
\hline Methergine & 6.4 & 1.93 & \\
\hline
\end{tabular}

Table 3: Comparison of blood loss in third stage of labour between the two groups.

\begin{tabular}{|c|c|c|c|}
\hline $\begin{array}{l}\text { Blood Loss in 3rd stage } \\
\text { of labour in } \mathrm{ml}\end{array}$ & Mean & SD & $\mathbf{P}$ \\
\hline Oxytocin & 302 & 75.6 & \multirow{2}{*}{0.414} \\
\hline Methergine & 282.8 & 58.27 & \\
\hline
\end{tabular}

The mean blood loss in third stage of labour in the oxytocin group was $302 \pm 75.6 \mathrm{ml}$ and in methergine 
group was $282.8 \pm 58.27 \mathrm{ml}$. $\mathrm{p}$ value $=0.414$ which is statistically insignificant (Table 3 ).

Table 4: Mean haemoglobin before and after delivery in both the groups.

\begin{tabular}{|c|c|c|c|c|}
\hline Variable & Group & Mean & SD & $\mathbf{P}$ \\
\hline \multirow{2}{*}{$\begin{array}{l}\text { Haemoglobin } \\
\text { before delivery } \\
\text { in } \mathrm{g} / \mathrm{dl}\end{array}$} & Oxytocin & 10.16 & 0.806 & \multirow[b]{2}{*}{0.666} \\
\hline & Methergine & 10.25 & 0.745 & \\
\hline \multirow{2}{*}{$\begin{array}{l}\text { Haemoglobin } \\
\text { after delivery } \\
\text { in } \mathrm{g} / \mathrm{dl}\end{array}$} & Oxytocin & 9.25 & 0.69 & \multirow[b]{2}{*}{0.566} \\
\hline & Methergine & 9.45 & 0.73 & \\
\hline
\end{tabular}

The mean $\mathrm{Hb} \%$ before delivery in the oxytocin group was $10.16 \pm 0.806$ and the mean $\mathrm{Hb} \%$ in the methergine group was $10.25 \pm 0.745$ with a $\mathrm{p}$ value 0.666 which is statistically insignificant. The mean $\mathrm{Hb} \% 24 \mathrm{hrs}$ after delivery in the oxytocin group is $9.25 \pm 0.69$ and in the methergine group is $9.45 \pm 0.73$ with a $p$ value 0.566 which is statistically insignificant (Table 4).

Table 5: Mean PCV before and after delivery in both the groups.

\begin{tabular}{|lllll|}
\hline Variable & Group & Mean & SD & P \\
\cline { 1 - 1 } $\begin{array}{l}\text { Before } \\
\text { delivery }\end{array}$ & Oxytocin & 29.908 & 1.737 & \multirow{2}{*}{0.120} \\
\cline { 1 - 4 } $\begin{array}{l}\text { After } \\
\text { delivery }\end{array}$ & Oxytocin & 30.12 & 2.147 & \\
\cline { 2 - 4 } & Methergine & 28.24 & 2.17 & \multirow{2}{*}{0.287} \\
\hline
\end{tabular}

The mean PCV in the oxytocin group was $29.908 \pm 1.737$ and in the methergine group was $30.12 \pm 2.147$ with a $\mathrm{p}$ value 0.120 which is statistically insignificant. The mean PCV $24 \mathrm{hrs}$ after delivery in the oxytocin group was $27.54 \pm 2.17$ and in the methergine group was $28.24 \pm 2.04$ with a $\mathrm{p}$ value 0.287 which is statistically insignificant (Table 5).

Table 6: Difference in $\mathrm{Hb}$ and PCV before and after delivery.

\begin{tabular}{|c|c|c|c|c|}
\hline Variable & $\begin{array}{l}\text { Study } \\
\text { group }\end{array}$ & Mean & SD & $\begin{array}{l}\text { P } \\
\text { value }\end{array}$ \\
\hline \multirow{2}{*}{$\mathrm{Hb}(\mathrm{g} / \mathrm{dl})$} & Oxytocin & 0.92 & 0.45 & \multirow{2}{*}{0.39} \\
\hline & Methergine & 0.81 & 0.34 & \\
\hline \multirow{2}{*}{ PCV \% } & Oxytocin & 2.36 & 1.424 & \multirow{2}{*}{0.12} \\
\hline & Methergine & 1.88 & 1.051 & \\
\hline
\end{tabular}

The mean fall in $\mathrm{Hb}$ in oxytocin group was $0.92 \mathrm{gm} \%$ and in methergine group was $0.812 \mathrm{gm} \%$. The $\mathrm{p}$ value is 0.399 which is statistically insignificant. The mean fall in PCV in oxytocin group was $2.36 \%$ and in methergine group was $1.88 \%$. $\mathrm{p}$ value $=0.12$ which is statistically insignificant (Table 6).

Two women in oxytocin group received additional uterotonic of $0.2 \mathrm{mg}$ methergine and one woman who received methergine had received additional dose of $0.2 \mathrm{mg}$ methergine (Table 7).
Table 7: Need for additional uterotonics.

\begin{tabular}{|ll|}
\hline Additional uterotonics & No. of cases \\
\hline Oxytocin & 2 \\
\hline Methergine & 1 \\
\hline
\end{tabular}

Table 8: Side effects.

\begin{tabular}{|c|c|c|c|}
\hline Side Effects & Oxytocin & Methergine & $\mathbf{P}$ \\
\hline Vomiting & 0 & 1 & \multirow{5}{*}{0.004} \\
\hline Nausea & 1 & 5 & \\
\hline Headache & 0 & 1 & \\
\hline $\begin{array}{l}\text { Rise in blood } \\
\text { pressure }\end{array}$ & 0 & 1 & \\
\hline Fever & 0 & 0 & \\
\hline
\end{tabular}

A total of 8 women who received methergine had side effects, one had vomiting, one had headache, one had rise in blood pressure and 5 had nausea, while only one had nausea in the oxytocin group with a p value 0.004 which is statistically significant (Table 8).

Table 9: Need for blood transfusion.

\begin{tabular}{|ll|}
\hline Blood Transfusion & No. of cases \\
\hline Oxytocin & 3 \\
\hline Methergine & 3 \\
\hline
\end{tabular}

Blood transfusion was given to women with $\mathrm{Hb}<8.5 \mathrm{~g} / \mathrm{dl}$ (24hours after delivery) and 3 women in both the groups received 1unit of blood transfusion (Table 9).

\section{DISCUSSION}

The third stage of labour is defined as the "interval from the complete expulsion of the fetus to the complete expulsion of the placenta and membranes". The average duration is about 15 minutes in both primigravidae and multiparae. ${ }^{3}$ This duration is reduced to 5minutes in active management. ${ }^{3}$

Two methods of management are currently in practice. ${ }^{4}$ Expectant and active management. Expectant management (traditional): In this, placental separation and its descent occur spontaneously or aided by gravity or nipple stimulation either manually or by breast feeding. Active management includes prophylactic administration of uterotonic agents, controlled cord traction and uterine massage

WHO recommends that sustained uterine massage is not needed in women who has received prophylactic oxytocin in prevention of PPH. However, uterine massage is strongly recommended in treatment of PPH. ${ }^{5}$ FIGO recommends that uterine massage after the delivery of placenta as the usual component of AMTSL. ${ }^{6}$ Active management of third stage of labour is superior to Expectant management in terms of blood loss, incidence of post partum haemorrhage, blood transfusions and other serious complications of third stage of labour. ${ }^{7,8}$ 
Postpartum haemorrhage is the most common third stage complication and is the leading cause of maternal mortality. PPH affects $4-6 \%$ of all deliveries. ${ }^{9}$ Amount of blood loss in excess of $500 \mathrm{ml}$ following birth of the baby (WHO). The average blood loss following vaginal delivery, caesarean delivery and caesarean hysterectomy is $500 \mathrm{ml}, 1000 \mathrm{ml}, 1500 \mathrm{ml}$ respectively. Another proposed definition for PPH by ACOG is a $10 \%$ decline in haematocrit. ${ }^{10}$ Coombs has suggested a clinical definition of "need for blood transfusion". ${ }^{11}$

$2 / 3^{\text {rd }}$ of PPH occur in women with no identifiable risk factors without proper management $\mathrm{PPH}$ can rapidly progress to cause life threading blood loss. Routine practice of active management of the third stage of labour has been shown to dramatically reduced haemorrhage by up to $60 \%$. Giving uterotonic drug within one minute of birth is the component of active management of third stage of labour (AMTSL) that has greatest impact on the prevention of PPH. Every attendant at birth needs to have the knowledge, skills and critical judgement needed to carry out active management of third stage of labour.

In our study we evaluated the efficacy of the two drugs oxytocin and methyl ergometrine by recording the duration and blood loss in third stage, $\mathrm{Hb}$ percentage and PCV before and after 24 hours of delivery, side effects and need for additional uterotonics and need for blood transfusions.

\section{Table 10: Mean duration of third stage of labour.}

\begin{tabular}{|lllll|}
\hline $\begin{array}{l}\text { Duration of } \\
\text { 3rd } \\
\text { labouge of }\end{array}$ & Group & Mean & SD & $\begin{array}{l}\text { P } \\
\text { value }\end{array}$ \\
\hline Present Study & Oxytocin & 6.68 & 2.17 & \multirow{2}{*}{0.88} \\
\cline { 2 - 4 } & $\begin{array}{l}\text { Methergine } \\
\text { Deepa R et al }\end{array}$ & 6.41 & 1.93 & \\
\cline { 2 - 4 } & Oxytocin & 6.28 & 2.55 & \multirow{2}{*}{0.74} \\
\cline { 2 - 4 } $\begin{array}{l}\text { Vethergine } \\
\text { Vandana S et }\end{array}$ & 6.44 & 2.42 & \\
al & Oxytocin & 4.42 & 1.96 & \multirow{2}{*}{0.24} \\
\hline
\end{tabular}

In the present study, the mean duration of third stage of labour in the oxytocin group was $6.68 \mathrm{~min}$ and in methergine group was $6.4 \mathrm{~min}$. p value $=0.88$ which is statistically insignificant. In the study conducted by Deepa $\mathrm{R}$ et al the mean duration of third stage of labour in the oxytocin group was $6.28 \mathrm{~min}$ and in methergine group was $6.44 \mathrm{~min}$. The $\mathrm{p}$ value was 0.74 which is statistically insignificant. ${ }^{12}$ In the study conducted by Vandana $\mathrm{S}$ et al the mean duration of third stage of labour in the oxytocin group was $4.42 \mathrm{~min}$ and in methergine group was 3.79 min. $\mathrm{p}$ value $=0.245$ which is statistically insignificant (Table 10). ${ }^{13}$

In the present study, the mean blood loss in third stage of labour in the oxytocin group was $302 \mathrm{ml}$ and in methergine group was $282.8 \mathrm{ml}$. p value $=0.414$ which is statistically insignificant. In the study conducted by Deepa $\mathrm{R}$ et al the mean blood loss in third stage of labour in the oxytocin group was $237 \mathrm{ml}$ and in methergine group was $224 \mathrm{ml}$. $\mathrm{p}$ value $=0.319$ which is statistically insignificant ${ }^{12}$. In the study conducted by Vandana $S$ et al the mean blood loss in third stage of labour in the oxytocin group was $166.64 \mathrm{ml}$ and in methergine group was $156.72 \mathrm{ml}$. $\mathrm{p}$ value $=0.66$ which is statistically insignificant (Table 11). ${ }^{13}$

Table 11: Distribution of blood loss ( $\mathrm{ml})$ in third stage of labour.

\begin{tabular}{|c|c|c|c|c|}
\hline Blood loss & Group & Mean & SD & $\begin{array}{l}P \\
\text { value }\end{array}$ \\
\hline \multirow{2}{*}{$\begin{array}{l}\text { Present } \\
\text { Study }\end{array}$} & Oxytocin & 302 & 75.61 & \multirow[b]{2}{*}{0.414} \\
\hline & Methergine & 282.8 & 58.27 & \\
\hline \multirow{2}{*}{$\begin{array}{l}\text { Deepa } \mathrm{R} \\
\text { et al }\end{array}$} & Oxytocin & 237 & 69.58 & \multirow[b]{2}{*}{0.319} \\
\hline & Methergine & 224 & 50.75 & \\
\hline \multirow{2}{*}{$\begin{array}{l}\text { Vandana } \\
\text { S et al }\end{array}$} & Oxytocin & 166.64 & 64.17 & \multirow[b]{2}{*}{0.666} \\
\hline & Methergine & 156.72 & 82.98 & \\
\hline
\end{tabular}

In the present study, the mean fall in $\mathrm{Hb}$ in oxytocin group was $0.92 \mathrm{gm} \%$ and in methergine group was $0.812 \mathrm{gm} \%$. $\mathrm{p}$ value $=0.399$ which is statistically insignificant. In the study conducted by Deepa $\mathrm{R}$ et al the mean fall in $\mathrm{Hb}$ in oxytocin group was $0.86 \mathrm{gm} \%$ and in methergine group was $0.82 \mathrm{gm} \%$. $\mathrm{p}$ value $=0.21$ which is statistically insignificant ${ }^{12}$. In the study conducted by Shilu $\mathrm{A}$ et al the mean fall in $\mathrm{Hb}$ in oxytocin group was $1.10 \mathrm{gm} \%$ and in methergine group was $1.20 \mathrm{gm} \%$. $\mathrm{p}$ value $=0.56$ which is statistically insignificant (Table 12). ${ }^{14}$

Table 12: Assessment of mean fall in Hbgm\%.

\begin{tabular}{|c|c|c|c|c|}
\hline Hb & Group & Mean & SD & $\begin{array}{l}P \\
\text { value }\end{array}$ \\
\hline \multirow{2}{*}{$\begin{array}{l}\text { Present } \\
\text { Study }\end{array}$} & Oxytocin & 0.92 & 0.45 & \multirow{2}{*}{0.39} \\
\hline & Methergine & 0.81 & 0.34 & \\
\hline \multirow{2}{*}{$\begin{array}{l}\text { Deepa } \mathrm{R} \text { et } \\
\text { al }\end{array}$} & Oxytocin & 0.86 & 0.07 & \multirow{2}{*}{0.21} \\
\hline & Methergine & 0.82 & 0.29 & \\
\hline \multirow{2}{*}{$\begin{array}{l}\text { Shilu A et } \\
\text { al }\end{array}$} & Oxytocin & 1.10 & 0.80 & \multirow{2}{*}{0.56} \\
\hline & Methergine & 1.20 & 1.00 & \\
\hline
\end{tabular}

Table 13: Assessment of mean fall in PCV.

\begin{tabular}{|lllll|}
\hline PCV & Group & Mean & SD & P \\
Present & Oxytocin & 2.36 & 1.424 & \multirow{2}{*}{0.12} \\
\cline { 2 - 4 } $\begin{array}{l}\text { study } \\
\text { Deepa R }\end{array}$ & Methergine & 1.88 & 1.051 & \\
et al & Oxytocin & 0.91 & 0.64 & \multirow{2}{*}{0.2} \\
\cline { 2 - 4 } $\begin{array}{l}\text { Shilu A et } \\
\text { al }\end{array}$ & Methergine & 0.93 & 0.65 & \\
\cline { 2 - 4 } & Oxytocin & 3.8 & 3 & \multirow{2}{*}{0.99} \\
\hline
\end{tabular}

In the present study, the mean fall in PCV in oxytocin group was $2.36 \%$ and in methergine group was $1.88 \%$. $p$ value $=0.12$ which is statistically insignificant. In the study conducted by Deepa $\mathrm{R}$ et al the mean fall in PCV in oxytocin group was $0.91 \%$ and in methergine group was $0.93 \%$. $\mathrm{p}$ value $=0.2$ which is statistically insignificant ${ }^{12}$. 
In the study conducted by Shilu Adhikari et al the mean fall in PCV in oxytocin group was $3.8 \%$ and in methergine group was $3.8 \%$. p value $=0.99$ which is statistically insignificant (Table 13). ${ }^{14}$

Table 14: Comparison of efficacy of other parameters.

\begin{tabular}{|llll|}
\hline & Variable & Oxytocin & Methergine \\
\hline $\begin{array}{l}\text { Present } \\
\text { study }\end{array}$ & $\begin{array}{l}\text { Additional } \\
\text { uterotonics }\end{array}$ & 2 & 1 \\
\hline $\begin{array}{l}\text { Blood } \\
\text { transfusion }\end{array}$ & 3 & 3 \\
\hline $\begin{array}{l}\text { Deepa R } \\
\text { et al }\end{array}$ & $\begin{array}{l}\text { Additional } \\
\text { uterotonics }\end{array}$ & 6 & 0 \\
\hline $\begin{array}{l}\text { Blood } \\
\text { transfusion }\end{array}$ & 0 & 0 \\
\hline $\begin{array}{l}\text { Adhikari } \\
\text { S et al }\end{array}$ & $\begin{array}{l}\text { Additional } \\
\text { uterotonics }\end{array}$ & 5 & 4 \\
\hline $\begin{array}{l}\text { Blood } \\
\text { transfusion }\end{array}$ & 2 & 1 \\
\hline
\end{tabular}

In present study a total of two women in oxytocin group received additional uterotonic of $0.2 \mathrm{mg}$ methergine and one woman who received methergine had received additional dose of $0.2 \mathrm{mg}$ methergine. Blood transfusion was given to 3 women in both the groups. In the study conducted by Deepa $\mathrm{R}$ et al 6 women of the oxytocin group required the use of additional uterotonics in the form of IM methergine and none of the women of either groups required blood transfusion. ${ }^{12}$ In the study conducted by Shilu Adhikari et al the incidence of use of additional uterotonics was almost the same (Table 14). ${ }^{14}$

Table 15: Comparison of side effects.

\begin{tabular}{|c|c|c|c|}
\hline & Variable & Oxytocin & Methergine \\
\hline \multirow{5}{*}{$\begin{array}{l}\text { Present } \\
\text { study }\end{array}$} & Vomiting & 0 & 1 \\
\hline & Nausea & 1 & 5 \\
\hline & Headache & 0 & 1 \\
\hline & $\begin{array}{l}\text { Rise in blood } \\
\text { pressure }\end{array}$ & 0 & 1 \\
\hline & Fever & 0 & 0 \\
\hline \multirow{6}{*}{$\begin{array}{l}\text { Adhikari } \\
\mathrm{S} \\
\text { et al }\end{array}$} & Variable & Oxytocin & Methergine \\
\hline & Vomiting & 1 & 1 \\
\hline & Nausea & 0 & 2 \\
\hline & Headache & 2 & 4 \\
\hline & $\begin{array}{l}\text { Rise in blood } \\
\text { pressure }\end{array}$ & 2 & 2 \\
\hline & Fever & 0 & 0 \\
\hline \multirow{6}{*}{$\begin{array}{l}\text { Deepa } \mathrm{R} \\
\text { et al }\end{array}$} & Variable & Oxytocin & Methergine \\
\hline & Vomiting & 0 & 8 \\
\hline & Nausea & 0 & 0 \\
\hline & Headache & 0 & 0 \\
\hline & $\begin{array}{l}\text { Rise in blood } \\
\text { pressure }\end{array}$ & 0 & 9 \\
\hline & Fever & 0 & 0 \\
\hline
\end{tabular}

In present study a total of 8 women who received methergine had significant side effects, one had vomiting, one had headache, one had rise in blood pressure and 5 had nausea, while only one had nausea in the oxytocin group. In the study conducted by Shilu Adhikari et al the side effects of the uterotonics did not cause any serious adverse events. All the adverse effects were mild and they subsided spontaneously and none of the women required any medications for these effects ${ }^{14}$. In the study conducted by Deepa $\mathrm{R}$ et al 8 women who received methergine had vomiting and 9 had rise in blood pressure. While those who were given oxytocin alone did not have any significant side effect (Table 15). ${ }^{12}$

\section{CONCLUSION}

The usage of oxytocin in the active management of third stage of labour is beneficial in reducing the blood loss and thus helps in preventing post partum haemorrhage. Oxytocin is very safe to use with least side effects and can be used even in high risk women, it can be used even in hypertensive women and in those with cardiovascular disease.

In this study comparing IM oxytocin 10units and IM methylergometrine $0.2 \mathrm{mg}$ given in the third stage of labour, it was found that both methylergometrine and oxytocin were equally efficacious in reducing blood loss in the third stage of labour and effective in reducing the duration of third stage of labour.

However, in the view of occurrence of side effects and its limitations of methylergometrine, it can be concluded that oxytocin is more preferable than methylergometrine in the active management of third stage of labour.

\section{ACKNOWLEDGMENTS}

Authors would like to thank Dr.Navin Puttum Assistant Professor of Emergency Medicine, Vinayaka Missions University, for Statistical Analysis and helped in manuscript preparation.

\section{Funding: No funding sources}

Conflict of interest: None declared

Ethical approval: The study was approved by the Institutional Ethics Committee

\section{REFERENCES}

1. India Maternal mortality rate - Demographics [Internet]. [cited July 9, 2017]. Available at https://www.indexmundi.com/india/maternal_mortali ty_rate.html

2. The World Health Report 2005 - make every mother and child count [Internet]. [cited 2014 Sep 3]. Available at http://www.who.int/whr/2005/en/

3. Dutta DC. Textbook of Obstetrics. 7th Edition, New Central Book Agency Pvt. Ltd;2011:117-42.

4. Arulkumaran S, Arjun G, Penna LK. The management of labour. $3^{\text {rd }}$ Ed. Hyderabad: 
universities press (India) private Ltd;2011;18:289295.

5. World Health Organization. WHO Issue recommendations for postpartum haemorrhage. Geneva-2012 [internet] [cited 2014 Sep 1] Available at

www.who.int/reproductivehealth/publications/matern al_perinatal_health/9789241548502/en/

6. FIGO Guidelines on the prevention and treatment of postpartum haemorrhage in Low-Resource settings [Internet]. [cited 2014 Sep 2]. Available at http://www.fogsi.org/index.php?option=com_content $\&$ view=article $\&$ id=351 \%3A figo-guidelines-onthe-prevention-and-treatment-of-postpartum

haemorrhage-in-low-resorce settings \&catid $=39 \% 3 \mathrm{~A}$ miscellanea \& Itemid $=238$.

7. The Cochrane Collaboration, editor. Cochrane Database of Systemic Reviews: reviews [Internet]. Chichester, UK:John Wiley and Sons, Ltd; 1996 [cited 2014 sep 3]. Available at http://apps.whoint/rhUguidelines/appraisal_pph/en/in dex.html

8. Active versus expectant management for women in the third stage of labour. [inteme] [cited 2014 sep 14] Available http://apps.who.int/rhl/pregnancy_childbirth /3rd_stage/cd007412_abalose_com/en/

9. Foley MR, Strong TH, Garite TJ. McGraw Hill Professional, 2004. Obstetric Intensive Care Manual 2nd edition. 2004; 24-7
10. American College of Obstetricians and Gynecologists. ACOG Practice Bulletin: Clinical Management Guidelines for ObstetricianGynecologists Number 76, October 2006: postpartum hemorrhage. Obstet Gynecol. 2006 Oct;108(4):1039-47.

11. Combs CA. Factors associated with postpartum haemorrhage with vaginal birth. Obstet Gynecol 1991;77:69-76.

12. Rajendran D, Mamatha S, Siddesh A, Gowda S. Oxytocin versus methyl ergometrine in the management of third stage of labor: a comparative study from a South Indian tertiary care hospital. Int J Reprod Contracept Obstet Gynecol. 2016;5:1327-30.

13. Vandana Satwe, Jyoti Salunkhe, Seema Satwe, Sheetal Samson. Injection Oxytocin versus Injection Methergine in Active Management of Third Stage of Labour. IJSR. 2014;3(3):353-8.

14. Adhikari S, Rana A, Bista KD. Active management of third stage of labour: comparison between prophylactic intramuscular methylergometrine and intramuscular oxytocin. Nepal J Obstet Gynaecol. 2007;2(2):24-8.

Cite this article as: Swapnika DRH, Priya GP, Priya SS, Allirathinam AS. A comparative study between intramuscular oxytocin and intramuscular methyl ergometrine in the active management of third stage of labour. Int J Reprod Contracept Obstet Gynecol 2018;7:1943-8. 